\title{
ESR2 wt Allele
}

National Cancer Institute

\section{Source}

National Cancer Institute. ESR2 wt Allele. NCI Thesaurus. Code C51575.

Human ESR2 wild-type allele is located in the vicinity of $14 q 23.2$ and is approximately 254

$\mathrm{kb}$ in length. This allele, which encodes estrogen receptor beta protein, is involved in transcriptional activation. 